\title{
The RR Project - A Framework for Relationship Network Viewing and Management
}

\author{
César Stradiotto ${ }^{1}$, Everton Pacheco ${ }^{1}$, Andre Bortolon', Hugo Hoeschl ${ }^{2}$ \\ 1 WBSA Sistemas Inteligentes SA, Parque Tecnológico Alfa, Centro de \\ Tecnologia thaSoft, SC $401 \mathrm{Km} 1$ - Módulo 10 - Térreo B - João Paulo - \\ 88030-000 - Florianópolis, SC - Brasil \\ \{cesar,evertonpp,bortolon, hugo\}@wbsa.com.br \\ WWW home page: http://Www.wbsa.com.br \\ 2 Instituto de Governo Eletrônico, Inteligência Jurídica e Sistemas - \\ IJURIS, Rua Lauro Linhares, 728 - sala 105 - Trindade - 88036-0002 - \\ Florianópolis - SC - Brasil \\ WWW home page: http://www.ijuris.org
}

\begin{abstract}
The Relationship Networks Project (RR - Redes de Relacionamento) is an innovative project, which intends to create a framework, which allows through a fast data modeling - implementing interface elements that describe in a clearly visual way, in two-dimensional presentation, a relationship network among beterogeneous items. This environment also allows the machine to do operations over these relations, such as to find paths or sets, to help the implementation of AI algorithms, or data extraction by the final user. Through graph theory, with visual items, it is possible to find elements with specific characteristics and relationships between them, by the application of filters, refining searches inside an extreme large datasets, or showing differentiated connection maps. Two prototypes were created with this framework: A system which allows seeing telephonic calls sets and financial transactions, and a system for ontology viewing for a digital dictionary inside a semantic network. Another software, in prototypical phase, also for semantic network vision, is being constructed. This document will present the basic RR structure, showing and justifying the creation of the two referred software above.
\end{abstract}

\section{Introduction}

Recent studies have directed its focus statistical properties of networked systems, like Internet or social networks. By Girvan [1] researchers have concentrated particularly on some common properties to many types of networks: the small world property, distribution degrees following potential functions, network transitivity, and one more property: the community structure, where the net nodes are grouped closely, and between these groups, there are some weak connections.

Jumping from mathematics to biology and linguistics, Barabasi [2] says that researches on networked systems also include items such protein actuation over

Please use the following format when citing this chapter:

Stradiotto, C., Pacheco, E., Bortolon, A., Hoesch1, H., 2006, in IFIP International Federation for Information Processing, Volume 218, Professional Practice in Artificial Intelligence, eds. J. Debenham, (Boston: Springer), pp. 121-130. 
Problems involving data relationship networks occurs with high frequency, needing media through which it can be possible the clear vision over these data. Together with that, data and relation types between them vary largely, depending on the problem scope.

In this way, software that could describe some type of data, inside a determined scope, could not fit for another type of problem, or it had to suffer some modifications to adequate to the new problem.

The Relationship Network Project (or in Portuguese: RR - Redes de Relacionamento) intends to allow the software project manager to implement in fast way a software that make two-dimensional demonstration of heterogeneous data, related by vertex and edges, including edition and analysis, and Artificial Intelligence tools.

In the following document it will be described two case studies involving the use of the same environment of RR project: 1) Vision and edition of telephone calls and money transferring, and 2) Vision of ontology dictionaries from a semantic network.

\section{Environment Basic Structure}

\subsection{Structure}

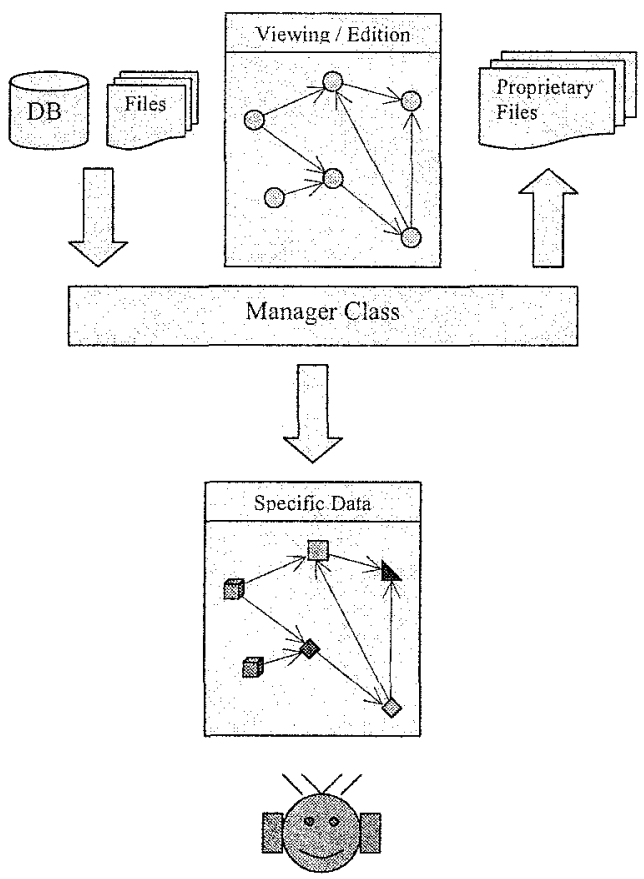

Fig. 1. Environment Basic Structure

The environment basic structure (Fig. 1) is composed by five modules: Management, Data Reading, Viewing / Edition, Specific Data, and Data Writing. Such structure 
allows maintaining the independent programming between these modules; in such a way that makes easy the implementation work to achieve the new entered data types.

Managing Module It's the module that contains the menus, which allows the user to execute the system main activities. Also contains rules that will be used by the Viewing / edition module, and filters, which can be applied to the working data.

In this module it's possible to choose the picture to represent the data from its type, or to execute filtering and require data reading or writing. Here are implemented also the Artificial Intelligence and Graph Theory algorithms, responsible by the automatic processing of the information about to be analyzed.

Data Reading Module Does the inclusion of data inside the system, be it originated on databases, electronic datasheet, proprietary files or formatted text. It does exist just to make compatible data from different natures, to be shown inside the viewing system as a linked network.

Viewing / Edition Module Responsible for showing the connected data to the final user, allowing its edition, navigation, and responsible for showing analysis results. This module is present inside any application for network data viewing developed over the RR environment.

Specific Data Module Contains the application specific data. And such application is built over the RR framework.

Data Writing Module Responsible for managing data persistence, in a proprietary format for the implemented application, or in a specific format, depending on the client's demand, allowing data compatibility with another framework or software.

\subsection{Used technologies}

The framework is done over Windows platform, with Borland $\mathrm{C}++$ Builder IDE. The communication with databases is done via ODBC. Visual Data are stored in proprietary format. 


\section{Interface}

The interfaced is based on MDI (Multiple Document Interface). So it allows many visual instances from many data groups (Fig. 2).

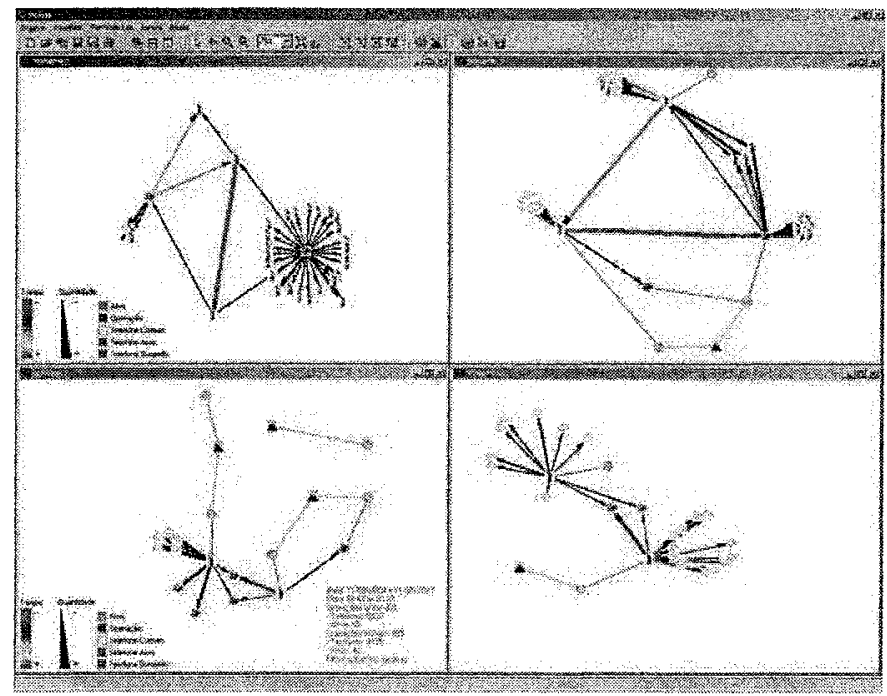

Fig. 2. MDI Application sample made with the RR framework.

\section{Case Studies}

\subsection{Telephone calls and financial transactions networks management}

\section{Telephony case}

Accordingly Siqueira [3] the numbers of telephone calls inside Brazil have raised $600 \%$ between 1994 and the beginning of 2002 , starting from 103 million calls a day to 715 million. In that time the country had 70 million telephonic accesses, being 40 million made by common telephones, against 30 million cellular. Each of these generating a mean number of 10 calls a day. In the same time, the number of Internet users jumped from 200 thousand to 14 million users, including voice, data and image traffic services.

Dias [4] says that in November of 2003, the numbers of cellular telephones was 43 million, and the number of common telephones was estimated to be about 39,4 million units. A good number of these calls made a network of illegal or criminal acts, being necessary its tracking under judicial orders for investigation and analysis. In this group are included common telephones, cellular telephones with voice and textual calls, modem's with Internet access, fax, and email messages, among others. Lobato [5] quotes the existence of 10 thousand judicial processes and queries involving fraudulent acts made by cellular and standing telephony in Brazil. These including public telephone cable deviation, cellular cloning, cold fiscal notes for stolen cellular telephone habilitation, and clandestine telephonic interception. 


\section{Financial Cases}

Correspondingly the news agency IDG NOW [6] "Trojan attacks, virtual mechanisms that induce users to give personal information like passwords or bank data, raised $1184 \%$ in Brazil, between July and December last year... In the same fime interval, the mean rate of attacks in another countries raised $293 \% . "$

Filho [7] affirms that money losses from Brazil to foreign countries through CC5 type cash accounts stands by US $\$ 40$ billion, due to law features, which allows such money transferring by secret ways, and without the payment of corresponding taxes to Brazilian Central Bank.

Mcdowell [8] enumerate some damage suffered by governments and enterprises, due to money-washing processes. Some quoted damages are:

- Exposition of emergent markets, where money-washing groups invests their money on properties or companies, creating monopolies or breaking that countries / companies taking back the invested money, without any accordance. Such behavior also damages the invested company public image;

- Creation of apparent companies, which can practice prices lower than that practiced on the local market, breaking concurrent industries;

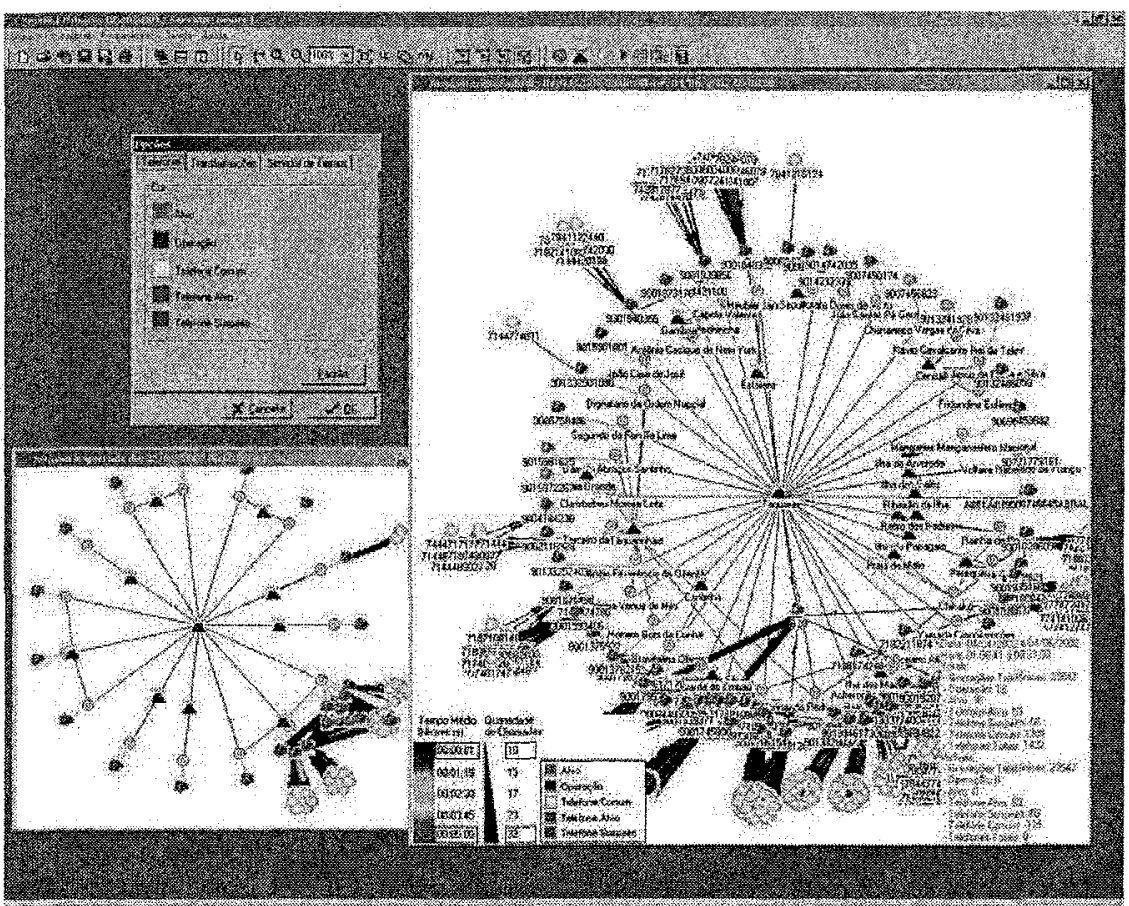

Fig.3. System for telephone calls data analysis. 
Observing the necessity of a tool to help investigators that works on problems like the ones described above, the RR framework was created initially as a basic module for a software able to make analysis of telephonic calls datasets [9] (Fig.3), being a graphic tool that clearly shows the worked data, able to give relevant information, even when the data is first viewed. This tool has filtering resources, edition modes, storage and data recovery, telephonic calls pathfinder and report generation. After that, the system was evolved for load, analysis and persistence also of financial transaction data (Fig.4).

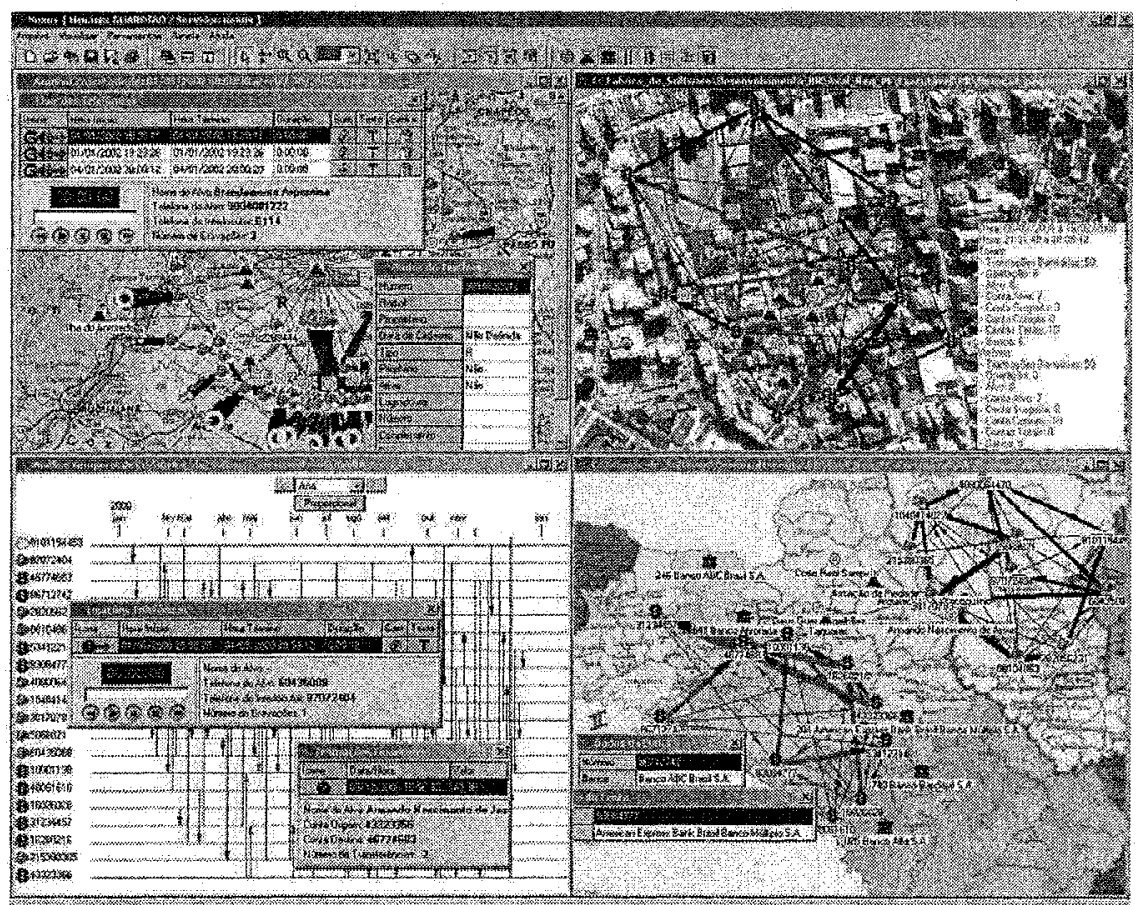

Fig. 4: Screen taken from the software for telephone calls and financial transactions analysis.

The system enables juridical area professionals, from police intelligence, security, and financial government organs, to track and store telephone calls by a totally automated and confidential way, without any human intervention inside this process. In this way the systems avoid totally the possibilities of fraud or human errors during the process of catching and storing calls, keeping the integrity and secrecy of investigative operations.

Following Mendroni [10] “... investigations made before prosecution acts may be necessarily secrets. If not, the investigation is frustrated by its beginning. For the same reason that a criminal does its illegal acts and does not reveal it to the competent authorities, these ones not only can, but have to investigate him - by obligation of its functions - ... without show its contents, until it can group enough data to made a convincement, and after all that, take the adequate decisions about that crime." 


\subsection{Vision of semantic networks}

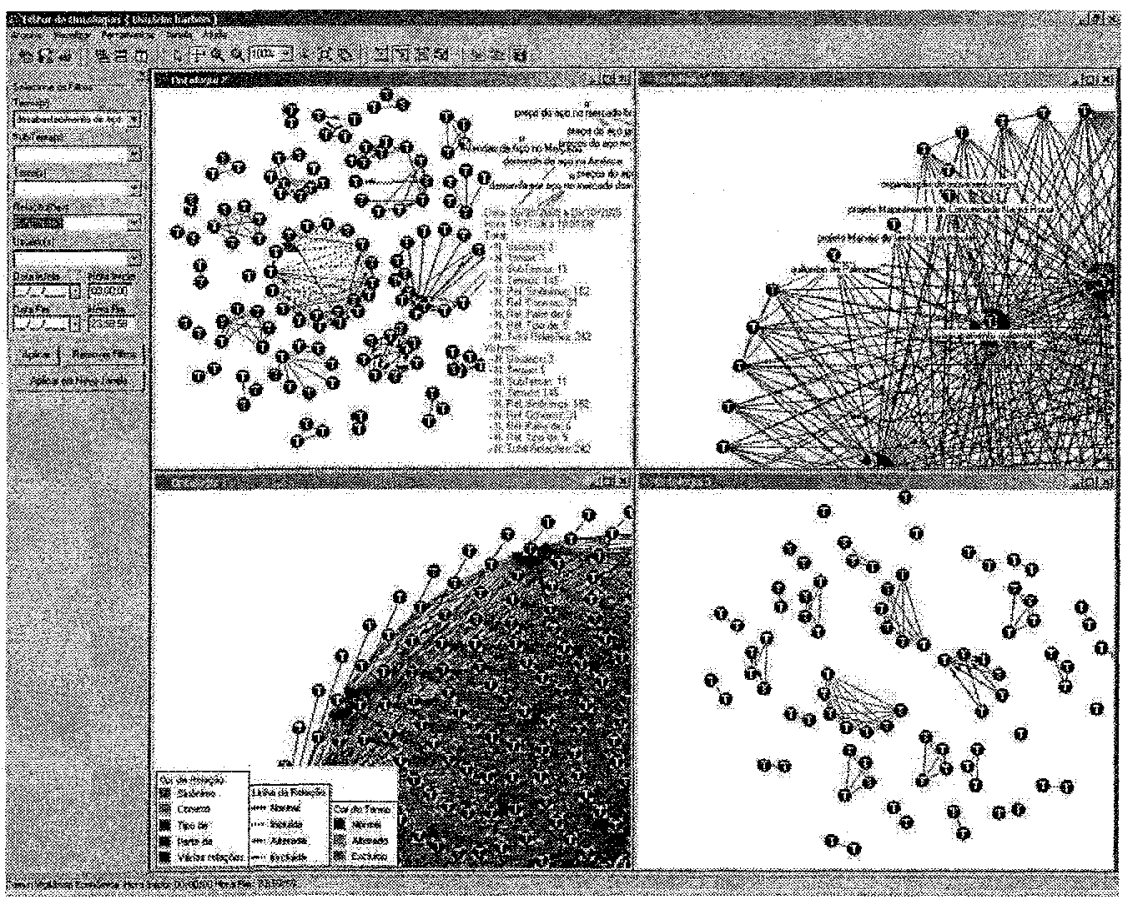

Fig. 5. Exemplo de ferramenta para visão de redes de ontologias.

The number of applications involving knowledge representation has increased more and more at last times, and many models used to implement these applications do these representations through semantic networks $[14,15,16,17,18]$. Such systems also need edition tools used by the responsible professional that takes care of these semantic nets.

Cawsey [19] affirms that a semantic network is a relationship network, where the nodes inside the graph represent concepts, and the edges represents binary relations between these concepts.

The RR framework goes inside there like a tool for viewing relationships, hierarchies and rules inside a semantic net production environment. A sample environment to produce ontologies is described on Bueno[20]. The first used prototype (Fig.5) was a case for edition of rules and relations for the ontology dictionary inside KMAI project [21]. The RR framework allows a clear visual disposal of the net, and inclusion of concepts and relations between them, all of these represented by vertex and edges. 


\section{Conclusions}

The RR framework fits initially for software that serves as a telephonic call analysis tool, causing a sensible impact in the way these types of data were analyzed, showing recently its first results. After that, the software evolved for a tool that can load and analyze data from financial transactions documents.

It served also for viewing and analysis of relations between concepts inside a semantic network, by this way improving the creation and revision of ontologies inside a production model.

By the fact that the RR framework is being used inside problems from so different domains, such fact shows its extreme versatility. Although these initial results, its applicability doesn't finishes here. The environment shows itself generic enough to deal with data from diverse types, from networks structured over simple lists to multimedia inside the web. To do all this, it's enough to have a protocol to feed de visual net inside the software that is done over the framework.

\section{Bibliography}

1. GIRVAN, Michelle.; Newman, M. E. J. Community structure in social and biological networks. Base de Dados arXiv.org - 07 dec. 2001. Disponivel em: $<$ http://arxiv.org/abs/cond-mat/0112110> página 2. Acesso em: 12 dez. 2003

2. BARABÁSI, A. L.; BONABEAU, E. Scale-Free Networks. Scientific American, New York. v.1, 7 dec. 2001. Disponivel em: <http:/www.nd.edu/networks/PDF/ScaleFree $\% 20$ Sci $\% 20$ Amer\%20May03.pdf $>$. p52. Acesso em: 14 Jan. 2004 - ISSN 0036-8733.

3. SIQUEIRA, E. Brasil fala 600\% mais que em 1994. 24 mar. 2002. O Estado de São Paulo. Disponivel em: <http://txt.estado.com.br/colunistas/siqueira/2002/03/siqueira020324.html >. Acesso em: $12 \mathrm{dez} .2003$

4. DIAS, J. A. Telefonia Atrairá Investidor Externo. Folha de São Paulo. 11 jan. 2004. Caderno Folha Dinheiro. Disponivel em: $<$ http://wwwl.folha.uol.com.br/fsp/dinheiro/fil101200410.htm>. Acesso em: $12 \mathrm{jan} .2004$.

5. LOBATO, E. Fraude Telefônica Fica Mais Sofisticada. 23 nov. 2003. Folha de São Paulo. Caderno Folha Cotidiano. Disponivel em $<$ http://www1.folha.uol.com.br/fsp/cotidian/ff2311200317.htm>. Acesso em: 30 nov. 2003.

6. IDGNOW .Cavalos de Tróia crescem 1184\% em 2004 http://idgnow.uol.com.br/AdPortalv5/SegurancaInterna.aspx?GUID=4D152F5C-4EB6-48849AAE-E301FDFD74E\$\&ChannelID=21080105 IDG NOW \SEGURANCA \ NOTÍCIA Publicado em 2 fevereiro de 2005.

7. FILHO, A.G.P. As contas $\mathrm{CC} 5$ e as instituições financeiras internacionais. Portal de $\begin{array}{lllll}\text { Contabilidade. } & 20 & \text { de janeiro } & \\ \end{array}$ http:/www.cosif.com.br/publica.asp?arquivo $=20050407$ cc5ilegais Acessado em janeiro de 2006.

8. MCDOWELL, J, NOVIS, G. As Consequuências da Lavagem de Dinheiro e dos Crimes Financeiros. Perspectivas Econômicas, Maio de 2001 http:/usinfo.state.gov/journals/ites/0501/ijep/ie0502.htm Acessado em novembro de 2005. 
9. STRADIOTTO, C. R. K.; BORTOLON, A.; HOESCHL, H. C.; MARAFON, M. J.. Ferramenta de Desenvolvimento de Software para Representação Visual de Redes de Relacionamento. In: CONGRESSO NACIONAL DE TECNOLOGIA DA INFORMAÇÃO E COMUNICAÇÃO, 2004. http://www.sucesu2005.com.br/palestras2004/24.html Acessado em Janeiro de 2006

10. MENDRoni, M. B. O Sigilo da Fase Pré-Processual. Revista Justitia, p1. São Paulo [2004] Disponivel em:

$<$ http://www.mp.sp.gov.br/justitia/CRIMINAL/crime\%2035.pdf>. Acesso em: jan. 2004.

11. BARRETO, A. S.; BUENO, T. C. D.; HOESCHL, H. C. Applying Case Based Reasoning to Knowledge Representation of Tributary Decisions. In: THE $9^{\text {th }}$ NNTERNATIONAL CONFERENCE ON ARTIFICIAL INTELLIGENCE AND LAW, 2003, Edimburgh. Proceedings... New York: Association for Computer Machinery (ACM) - p. 77. ISBN 158113-747-8.

12. BUENO, T. C. D. et al. Using RBC to Classify Judicial Petitions on e-Court. In: THE $9^{\text {th }}$ INTERNATIONAL CONFERENCE ON ARTIFICIAL INTELLIGENCE AND LAW, 2003, Edimburgh. Proceedings... New York: Association for Computer Machinery (ACM) - p83. ISBN 1-58113-747-8.

13. COSTA, F.C.; BUENO, T.C.D.; RIBEIRO, E.B.Q. New Procedures for Environmental Licensing with Artificial Intelligence - CIPPLA. In: THE $9^{\text {th }}$ INTERNATIONAL CONFERENCE ON ARTIFICIAL INTELLIGENCE AND LAW, 2003, Edimburgh. Proceedings... New York: Association for Computer Machinery (ACM) - p87. ISBN 158113-747-8.

14. HOESCHL. H.C. et al. Dynamically Contextualized Knowledge Representation of the United Nations Security Council Resolutions. In; THE $9^{\text {th }}$ INTERNATIONAL CONFERENCE ON ARTIFICIAL INTELLIGENCE AND LAW, 2003, Edimburgh. Proceedings... New York: Association for Computer Machinery (ACM) - p. 95. ISBN 1 $58113-747-8$.

15. HOESCHL. H.C. et al. Knowledge-Based System Applied on the Previous Consent of Brazilian National Defense Council. In: THE $9^{\text {th }}$ INTERNATIONAL CONFERENCE ON ARTIFICIAL INTELLIGENCE AND LAW, 2003, Edimburgh. Proceedings... New York: Association for Computer Machinery (ACM) - p. 97. ISBN 1-58113-747-8.

16. MATTOS, E.S. et al. A Knowledge Base for Automatic Capitulation in Expert System. In: THE $9^{\text {th }}$ INTERNATIONAL CONFERENCE ON ARTIFICIAL INTELLIGENCE AND LAW, 2003, Edimburgh. Proceedings... New York: Association for Computer Machinery (ACM)-p. 99. ISBN 1-58113-747-8.

17. RDF. Resource Description Framework. Disponivel em: <http:/www.w3.org/RDF/ $>$. Acesso em: jan. 2004.

18. XU, Z.; WU, J. A Survey Of Knowledge Base Grid For Traditional Chinese Medicine. In: THE FIFTH INTERNATIONAL CONFERENCE ON ENTERPRISE INFORMATION SYSTEM, v. 4. Software Agents and Internet Computer, 2003, Angers. Proceedings... Setúbal: Escola Superior de Tecnologia de Setubal. p. 136. ISBN: 972-98816-1-8. Disponível em: < http://www.iceis.org>. Acesso em: 19 jan. 2004. 
19. CAWSEY, A. Semantic Nets. Disponivel em: <http:/www.cee.hw.ac.uk/ alison/ai3notes/subsection2 4_2 1.html >. Acesso em: jan. 2004.

20. BUENO T. C. D et al. Knowledge Engineering Suite: a Tool to Create Ontologies for Automatic Knowledge Representation in Knowledge-based Systems. in: The 2nd International Workshop on Natural Language Understanding And Cognitive Science (NLUCS-2005) in ICEIS - 7th international conference. Proceedings of 7 th International Conference On Enterprise Information Systems. 2005.

21. RIBEIRO, M. S. KMAI: da RC2D à PCE. 2003. 190f. Dissertação (Mestrado em Engenharia de Produção) - Universidade Federal de Santa Catarina, Florianópolis, 2003. 